Cinémas

Revue d'études cinématographiques

Journal of Film Studies

STAM, Robert, BURGOYNE, Robert, FLITTERMAN-LEWIS, Sandy. New Vocabularies in Film Semiotics : Structuralism, Post-structuralism, and Beyond. London/New York : Routledge, 1992, 239 pp.

\title{
Wojciech Kalaga
}

Volume 4, numéro 3, printemps 1994

URI : https://id.erudit.org/iderudit/1001044ar

DOI : https://doi.org/10.7202/1001044ar

Aller au sommaire du numéro

Éditeur(s)

Cinémas

ISSN

1181-6945 (imprimé)

1705-6500 (numérique)

Découvrir la revue

Citer ce compte rendu

Kalaga, W. (1994). Compte rendu de [STAM, Robert, BURGOYNE, Robert, FLITTERMAN-LEWIS, Sandy. New Vocabularies in Film Semiotics :

Structuralism, Post-structuralism, and Beyond. London/New York : Routledge, 1992, 239 pp.] Cinémas, 4(3), 167-175. https://doi.org/10.7202/1001044ar d'utilisation que vous pouvez consulter en ligne. 
Stam, Robert, Burgoyne, Robert, Flitterman-Lewis, Sandy. New Vocabularies in Film Semiotics: Structuralism, Post-structuralism, and Beyond. London / New York: Routledge, 1992, 239 pp.

For the first time since reading Cortazar's Hopscotch many years ago - though in a different context and with a different disposition - I have had an impression of reading more than one book at one time. Unlike Cortazar, however, who sought to achieve ambiguity and opalescence, the authors of New Vocabularies in Film Semiotics aim at precision and clarity: their objective is to explain the conceptual apparatus of both general semiotics and of semiotically oriented film studies. Yet the book is much more than just a compendium of the vocabulary of the discipline: it is in equal measure a comprehensive introduction to the history of film semiotics and to its theoretical origins, as well as a general but very informative introduction to the methodological and ideological problematics dominating contemporary debates and polemics. Devoted primarily to film, it outlines prevalent tendencies within semiotic studies in the humanities. By boldfacing and explaining appropriate entries within the narrative about the development of particular phases or "branches" of film semiotics, the authors succeeded in combining a lexicon with an advanced textbook. The reader can either follow the lecture page by page, or use the alphabetical index to find a definition of the required term.

As a textbook or guide to the field, the volume consists of five parts of which each is concerned with a different aspect of film studies. Chronology is maintained within each of the parts, but is not the organizing principle of the book as a whole.

The introductory part ("The Origins of Semiotics," R. Stam) excellently foregrounds the role of early "pre-semiotic" trends 
in creating and establishing the theoretical and methodological background for the subsequent development of the semiotic apparatus, as well as the influence exerted by those early developments upon contemporary theorists or movements (e.g., the influence of Saussure and the Formalists upon structuralist semiotics in general and Christian Metz in particular). The reader is taken for a swift but illumminating excursion through several decades from de Saussure through Formalism, the Bakhtin School, Prague structuralism (including Jakobson's early and later contributions) to the Western structuralism and finally to the crisis of the sign in the post-structuralist writings of Derrida. Even though the authors do not rely on the semiotic tradition emerging from Charles S. Peirce's work (apart from a couple of basic terms like interpretant, iconic, infinite semiosis), they do point to the crucial differences between that tradition and the Saussurean semiology, and include an accessible comparison of the Peircean triadic sign with the Saussurean dyad (though I have found the discussion of the concept of interpretant somewhat disappointing: it was a good but unused opportunity to juxtapose the mentalism of the Saussurean sign with the nonpsychologistic character of the triad).

The extensive discussion of the linguistic turn in part one proves very useful in the next section ("Cine-semiology," Stam) where the authors discuss the long standing practice of comparing cinematic codes to language, and the linguistic nature of the cinema. The dominating character in this part is Christian Metz and the whole chapter revolves around the problems related to his Grande syntagmatique. Metz returns again in Part IV devoted to "Psychoanalysis" (S. Flitterman-Lewis). Again, the discussion of psychoanalytical film theory is preceded by an explanatory introduction of basic terms and a brief survey of both the classical Freudian and the Lacanian versions of psychoanalysis, with much emphasis on the linguistic character of the latter and on the reinterpretation of Freud by Lacan. Lacan's concept of the subject as process is contrasted with its counterpart in ego psychology where the ego is considered as unified and coherent self. Because of the fundamental interest of psychoanalysis in the construction of the subject, the focus changes now from the 
analysis of meaning in films to the production of subjectivity: the psychoanalytical theory of film is seen as "a move from the analysis of meaning as a content to the analysis of meaning as a structuring process" (141) and, consequently, a replacement of "the cinema as an 'object' by cinema as a 'process." (123) The focus on the spectator and spectatorship involves not only the question of gaze but also of enunciation as its counterpart and, inevitably, makes the problematics of gender central to psychoanalytical theory. The last section of part IV is devoted to the feminist film theory and centers on the questions of how "masculinity and femininity are constituted in the symbolic and discursive processes, and [how] this implies that sexuality itself is not a content, but a set of positions that are reversible, changing, conflictual." (178)

Part III (“Film-narratology,” R. Burgoyne) contains a useful survey of general approaches to questions of narrative structure (formalist, structuralist, semantic and syntactic, the Proppian and the Levi-Straussian models, and of course Genette) as well as a survey of film-specific stances. The discussion of narration in film makes it clear that relatively simple categories of literary narratology have to be translated into far more subtle terms when it comes to film analysis (an excellent example being the point of view and the derivative notions of focalization and ocularization). Apart from classical theories mentioned above, the authors discuss more recent writers on the subject, including Bordwell, Branigan, Browne, Jost, Rimmon-Kenan and others. In effect, the reader obtains a panoramic survey and a grid of analytical concepts to enable him/her to approach questions of narration, character, and perspective in film.

The last section of the book ("From realism to intertextuality, " Stam) is, as its title reveals, a depiction of a transition, or rather transitions : from world to text, from transparency to selffocus and self-reflexivity, from a closed text to an open text, from a realist text to intertextuality, from text as object to text as discourse, from the readerly to the writerly, from work to écriture, or most generally: from structuralism to post-structuralism and beyond. This last chapter reflects the general aura and tendency of the book: "to forge a critical and theoretical practice 
which would synthesize the interdisciplinary thrust of firstphase (structuralist) semiotics with the critique of mastery and the unified subject characteristic of post-structuralism, all combined with a trans-linguistic 'social semiotic' alert to the cultural and political inflections of the 'life of signs in society." (p. 220)

Considered as a lexicon, the book contains terminology which is not limited to cinematic entries. The authors make it clear from the very beginning that the terminological apparatus of the film-making practice cannot be sufficient for the analysis of film either as a work of art, as an ideological statement, or as a signifying practice, and that a special vocabulary has to be used for the sake of such analyses. That vocabulary has been developed, during the last several decades, by what can be called a semiotic approach to language, art, literature, and textuality in general. The book then is not a reference guide to film terminology, but a selective "dictionary" (or better, lexicon) of film semiotics: the reader looking for definitions of terms like reverse shot, iris, flicker film, or other technical phrases will have to turn to more specialized sources. On the other hand, he or she will find entries rarely or never explained in technical dictionaries, but indispensable to anyone who wants to undertake a discussion of cinema and film in systematic rather than impressionistic terms. (Still, an occasional brief explanation of more film-specific words would be a help to a non-professional reader).

The selection of entries is more than exhaustive, to the extent that words and phrases in the lexicon are not always the already codified terms established as the generally accepted vocabulary of the discipline, but include new coinages and novel terminological suggestions (I point to the advantages of such suggestions below). Occasionally, a couple of boldfaced terms arise doubts as to the validity of choice (e.g., partial answer from Barthes's $S / Z$, seems to speak for itself in its ordinary usage; or resistant films, formally resistant films, or content-oriented political films, from a paper by Comolli and Narboni, are descriptive idiosyncratic phrases rather than terms or concepts, just like political valence of reflexivity is not a term but a problem), but on the 
whole it is better to have too many than too few entries. This kind of heterogeneity - the inclusion of well established "classical" terms like representation, binary oppositions, defamiliarization or the dominant, and the new "classics" like self-referentiality, différence or hyper-reality, alongside novel coinages of the type mentioned above - has been intentional (as the authors declare in the Preface), and should be praised rather than criticized because it gives the book (or its dictionary aspect) a wideranging scope; apart from strictly film related entries the reference guide encompasses several planes: a theoretical semiotic vocabulary combined with basic linguistic, psychoanalytical, and literary terms, more or less directly relevant to the study of the cinema. (A minor remark: it may have been useful, particularly for a novice, to highlight more central or established terms in order to differentiate them from those which are either introduced by the authors or raised to the status of a term.)

As a lexicon, New Vocabularies should also be praised for the accessibility of its explananda. Despite complexity of many of the terms, explanations and definitions are lucid without being simplistic, and will satisfy a beginner as well as an intermediate or advanced student. While maintaining a fairly advanced theoretical level of the discussion, the authors also keep in mind the needs of a less experienced reader and supply numerous examples to illustrate theoretical concepts (the only, minor, objection perhaps could be that the difference between langage and language on p. 34 has not been explained sufficiently to be clear to a novice). What is particularly important - and what at the same time is one of the original contributions of the book - is that brief analytical examples from cinema are supplied for terms and concepts which are not specifically cinematic and which have been imported into film theory from other fields, and particularly from literature. A representative sample of such exemplification is the discussion of Genette's transtextuality (p. 206), where all the rich filmic illustration comes from the author of the section (Stam) rather than from Genette, who uses primarily literary examples. On the whole, exemplification throughout the book is very well selected, thoroughly accessible and convincing. 
Transtextuality exemplifies also another useful routine which the authors have adopted: apart from explaining concepts already established or emerging as important in recent literature, they themselves - where it seems desirable for the practice of cinematic discourse - coin terms which supplement the conceptual apparatus (e.g., celebrity intertextuality, genetic intertextuality, mendacious intertextuality under the main heading of intertextuality). Frequently, this kind of splitting of a term into several sub-terms opens interesting theoretical questions (e.g., the critique of reflexivity on pp. 201-202, or the genetic intertextuality mentioned above).

What could disturb a less experienced or less well read student - and in particular the one who uses the book not so much as a dictionary but rather as an introduction to film semiotics - is the practice of using a specialist (semiotic, linguistic, psychoanalytical, or cinematic) term without any crossreference to its explanation or definition in a later part of the book: e.g., on p. 20 secondary articulation is used but defined only on p. 32 ; on p. 10 the author mentions Jakobson's functions of language which - as the reader discovers for him/ herself - are discussed in detail seven pages later; other examples include scopophilia (used on p. 22, explained on p. 160), voyeurism $(22,160$, resp.), gaze $(84,162)$, family romance $(147,155)$, etc. This practice forces the reader to refer to the index more often than necessary, which is a distracting and sometimes a disappointing routine.

On the whole, the internal organization of the book very well matches its objectives. The passage devoted to Metz in part II epitomizes the method of the whole text: a combination of summary, diachronic background (origins, traditions, roots, influence of predecessors), criticism or polemics that a given concept or theory gave rise to as well as some critical evaluation. All those components are properly balanced to suit the didactic purpose of the book, without unnecessary details or too many names of minor forerunners or adversaries (the polemics, for instance, are presented rather as clashes of tendencies than of particular authors). At the same time, however, when a term or concept turns up that demands reference to a later debate rather 
than only a brief definition, the authors do not refrain from "anachronic" excursions, much to the benefit of the reader. (Some dispensable anachronisms, however, occur when first dates of publications of older works are missing: Booth is correctly given credit for the concept of the implied author, but 1983 as the date of publication of his The Rhetoric of Fiction (introducing the concept) may be very misleading to a freshman (p. 101); no wonder then - for the same reason that in a work published in 1981 "Bakhtin argues in terms recalling Metz," whereas in fact the resemblance should be reversed.) The authors draw a synthetic picture of the discipline without neglecting the milestones or works of significant importance for its development. More important contributions, both books and articles, are discussed almost in a form of mini-reviews, thus providing the student with a useful and informative reference that can possibly be pursued in greater detail, particularly since the authors frequently point to the more and the less productive aspects of particular theories, and to the links of film theory with other disciplines and most of all with literary theory.

That link between literary and film studies and their apparatus becomes particularly visible in the chapters on the origins of semiotics, on narratology and on intertextuality where the literary contributions including those of the formalists, Jakobson, Propp, Levi-Strauss, Barthes and semiotically oriented literary narratology are shown to have exerted either a direct or an indirect influence on film. One of the important contributions of the book is the depiction of the significance of Bakhtin's precursory work and of the relevance of his conceptual apparatus for contemporary film studies. The only instance when very strong literary origins are partly disregarded is the discussion of the point of view; the authors do refer to a work by Todorov, but do not mention the whole literary tradition of the point of view studies and analyses (Henry James, Percy Lubbock, Friedman). What perhaps justifies this particular instance of marginalization of the literary origins of a theoretical concept - apart from the limitations of space - is the fact that the question of the point of view in the literary work is by far less complex than in film. The cinematic intricacies of the problem of point of view 
and its implications for analytical procedures are shown in an exhaustive, but at the same time in a very lucid and accessible manner.

What could be a flaw in an argument more committed to a particular stance or in a polemical text - a certain methodological modesty or neutrality - is actually a merit of this work. The authors remain in the background and, within reasonable limits, try to withhold their own theoretical or methodological commitments and hierarchies of values from the main narrative. This reflects the objective defined in the Preface: "The book is intended as a didactic introduction to the vocabulary of the field, not as a series of interventions in film theory." (XIV) Even though the authors do not, in general, critique the theories or concepts they outline, they do occasionally point to certain methodological or practical consequences that ensue from a given theory, to its compatibility or incompatibility with others, or to - sometimes non-manifest - inconsistencies, tensions or contradictions within a theory, a term, or a group of terms (for example, in the case of the synchronic-diachronic dichotomy, or in the case of female enunciation, where the postulated concept of a woman per se is in contradiction with "the move to designate the textual production of gendered authorship.” (pp. 179181)

It is worth stressing that the same kind of authorial modesty - which could also be called methodological objectivism dominates discussions of those contemporary trends in semiotics or psychoanalysis which foreground their ideological or political pursuit: "the left wing [which] deployed semiotics as a means of demystifying cinematic representation, exposing it as a constructed system of socially informed signs" (22), or the feminist stream aiming - via similar procedures - at overthrowing the patriarchal systems of power and domination. The authors discuss those trends with methodological and theoretical faithfulness but at the same time with a critical distance sufficient to avoid ideologically postulative or agitative pronouncements.

If one insisted on being pedantic, one would have to mention a couple of technical slips: on pp. 213, 216 Norris 1990 and 
Kellner 1989 are referred to, but are missing from the bibliography. Baudouin de Courtenay (p. 12) was a Polish, not a Russian linguist (or, at least, his nationality was Polish); on p. 32 in a rather important statement: "The temptation to equate phoneme with 'word' was resisted because single words can include a number of morphemes," it seems that "morpheme" should have been used instead of "phoneme"; also ostranene (defamiliarization) seems a more common and a more faithful transcription of the Russian term than ostrenanie. The fact, however, that I am singling out such details in the critical part of this review should speak for itself: as a whole, the book evades any serious criticism and deserves praise as an excellently devised and very competently realized didactic project. If we substitute "merit" for "difference" in the authorial declaration from the Preface below, we shall obtain its appraisal in a nutshell: "The specific 'difference' [merit] of this book [...] lies (a) in its inclusiveness - almost six hundred terms and concepts are defined - (b) in its methodological range, its incorporation of a wide spectrum of theoretical grids and disciplinary discourses and (c) in its attempt to reconcile diachrony and synchrony, history and system, through a history of semiotics embedded in what is fundamentally a conceptual lexicon." (XIV) In all these three aspects, New Vocabularies is very successful: it is a book written with a highest level of professional expertise and should be recommended not only to students of film - possibly as an introductory coursebook - but of the humanities in general. In different ways, it will prove useful to an undergraduate, a postgraduate and a professor.

WOJCIECH KALAGA

Murdoch University (Australia) 